\title{
Evaluating the Impacts of Food Safety Policies on Japan's Rice Imports Based on the Simultaneous Buy and Sell System
}

\author{
Qianhui Gao* \\ School of Economics and Management, China University of Mining and Technology, Xuzhou 221116, China \\ *Corresponding author: Qianhui Gao, qianhuigaocumt@126.com
}

\begin{abstract}
This study evaluated the impacts of food safety policies on Japan's Simultaneous Buy and Sell rice imports through measuring tariff equivalents of food safety policies. In order to construct an estimated model, a Japanese consumer's utility function is introduced and developed with consumer's preference parameters and elasticity of substitution. In the empirical study part, Japan's positive list system and rice traceability were analyzed and assessed as critical food safety policies. Results showed that after the implementation of the positive list system, consumers' preference for foreign rice and the substitution elasticity diminished. This decreasing tendency was quite similar to the results after the enforcement of rice traceability. The tariff equivalents of food safety policies on imported rice fluctuated around $¥ 50$ yen/kg from fiscal year 2000 to 2005 and decreased because of the global grain price hike after 2006. The tariff equivalents soared in 2010, which was induced by the traceability regulation, and then dulled during Japan's earthquake and tsunami in 2011. Subsequently, after the recovery from natural disasters, the tariff equivalents of food safety policies became higher. Therefore, food safety policies had made imported rice less attractive, weakened the competitive power of rice exporting countries, and had statistically significant impacts on Japan's rice importation.
\end{abstract}

Keywords: Agricultural technology; Evaluating food safety policies; Positive list system; Simultaneous Buy and Sell system; Traceability

Publication date: August 2021; Online publication: August 30, 2021

\section{Introduction}

Rice is a staple food in the traditional Japanese diet. Especially, short-grain rice is a far more popular principal food in Japan than long-grain rice, which is mainly used for processed food, animal feed, or overseas donation. Local rice farming is strongly protected in Japan by domestic subsidy policies and stringent restriction on rice imports. Japan's rice self-sufficiency ratio was about $91 \%$ in $2016^{[1]}$.

Japan partly opened its rice market to the world in 1995 through the Uruguay Round and permitted minimum access (MA) of foreign rice as a rice importer ${ }^{[1]}$. The MA project allows a certain number of imported rice to be exempted from tariff when entering into Japan. MA rice imports are subjected to a lower markup of $¥ 292 \mathrm{yen} / \mathrm{kg}$. Other than this grace plan, the additional imported rice which was imposed on a prohibitive tariff of $¥ 351 \mathrm{yen} / \mathrm{kg}$ was reduced to $¥ 341 \mathrm{yen} / \mathrm{kg}$ in 2000 . The import quota of MA rice has been fixed at 767 thousand tons since the fiscal year 2000, which consists of the Ordinary Market Access (OMA) for medium and long-grain rice and Simultaneous Buy and Sell (SBS) for short-grain rice. In the MA scheme, the quota of SBS rice has been adjusted to 100 thousand tons every fiscal year.

SBS import quota actually comprises of SBS general rice and SBS broken rice. Broken rice that is 
primarily applicable to food processing and animal feeding only takes up a small proportion of the quota. The majority of the SBS quota, which is the SBS general rice, is the study subject in this research. The Ministry of Agriculture, Forestry, and Fisheries (MAFF) of Japan organizes the quota tenders while rice wholesalers and traders jointly bid for SBS rice of any origin and category. During the process of quota tender, importers sell foreign rice to MAFF and simultaneously buy it back. MAFF allocates the quota to those importers who maximize the markup.

Japan's SBS general rice was mainly imported from China before 2013, followed by imports from the United State of America (U.S.A.), Australia, Thailand, Pakistan, and other countries. Figure 1 clarifies Japan's SBS general rice imports from China, U.S.A., and other countries in each fiscal year. Besides, the movements of the average markup for SBS general rice from all over the world are also shown in Figure 1.

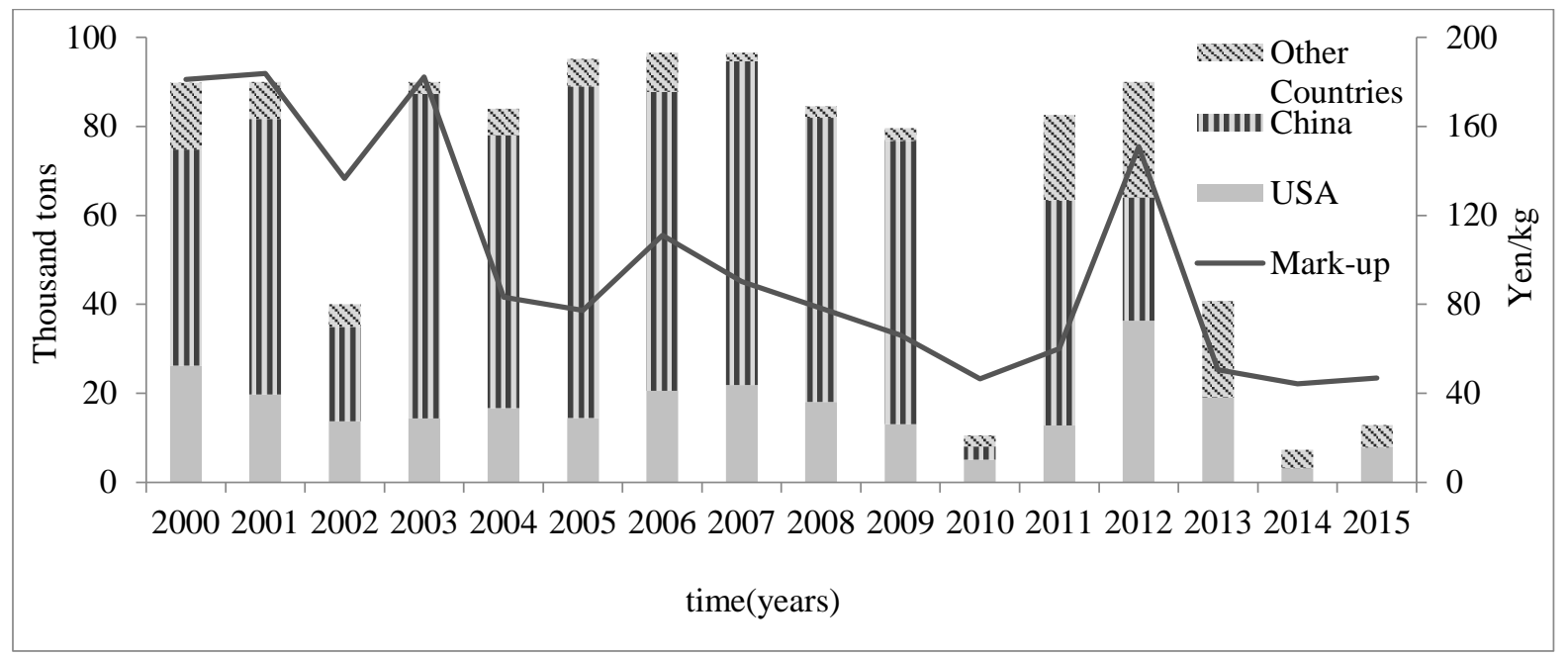

Figure 1. Quantity and markup of imported SBS general rice by source

Note: Data was collected from the MAFF of Japan, http://www.maff.go.jp/j/seisan/boueki/nyusatu/index.html

In order to examine and compare the prices, wholesale prices of four types of domestic rice in Japan and selling prices of SBS general rice by MAFF are shown in Figure 2. Although the imported rice was imposed on markup, SBS general rice to some extent still had price advantages.

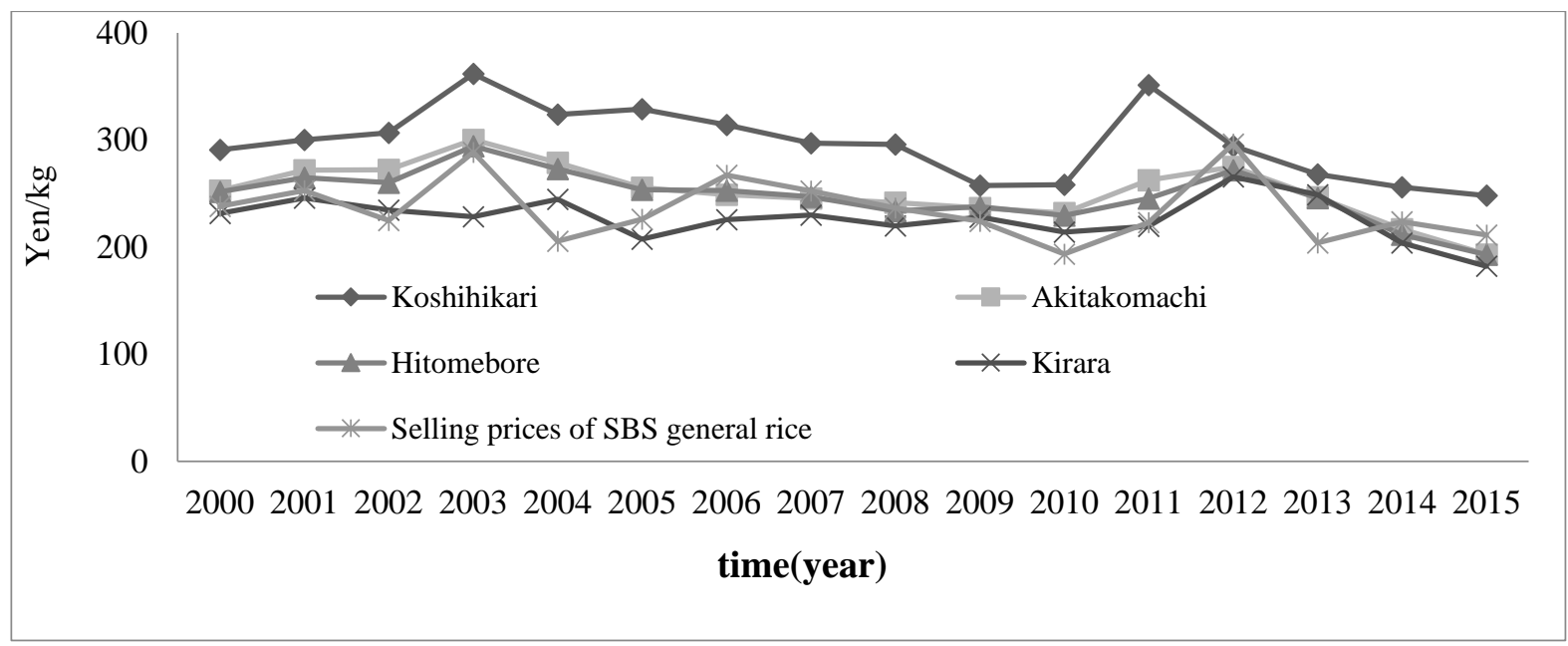

Figure 2. Wholesale prices of Japan's Rice and selling prices of SBS general rice

Note: Data was collected from the World Food Statistics and Graphics, http://worldfood.apionet.or.jp/graph/index-e.html 
The history of Japan's food safety policies can be traced back to the 1940s, where the principles of those policies were guaranteeing the food quality and offering food for human health security consumption. Japan has implemented various laws and regulations to supervise its food safety system, covering all kind of food, such as agricultural and forest plant products, livestock goods, aquatic products, etc., and involving many aspects such as planting, producing, processing, distributing, etc. Among these food safety policies, the positive list system is important for Japan's rice consumption because the system controls the chemical residues in the products. Japan has enforced the positive list system since May 2006, concentrating on agricultural chemicals remaining in food. According to the positive list system, the 283 initially prohibited chemical substances have been expanded to 799 substances regulated by the maximum residue limits (MRLs). Other than the chemical substances that are specified in the MRLs, chemicals have to comply with a certain level, in which unhealthy substances should be less than 0.01 parts per million, restricted by the positive list system to keep consumers safe and healthy.

Another significant food safety policy is food traceability. Japan introduced a handbook of food traceability systems in 2003, which became the primary reference and provided a comprehensive guidance for food safety standards. Japan's food traceability systems which cover many categories of food have been complemented and improved since being implemented so that food can be traced throughout the whole supply chain, from the place of production to the end consumer. In 2009, Japan promulgated the rice traceability regulation that required rice producers, dealers, and processors to conserve their transaction records from 2010 and publish the information of rice origin and delivery from 2011.

Many scholars had developed empirical models to estimate the influence of food safety laws and regulations. For example, the gravity-based model ${ }^{[2-9]}$, price-wedge method ${ }^{[10-13]}$, inventory-based method ${ }^{[14-16]}$, cost-benefit measurements based on risk assessment ${ }^{[17-19]}$, game theory ${ }^{[20-23]}$, and general or partial equilibrium models ${ }^{[24-27]}$ were extensively applied in their studies. Some researchers had adopted dummy variables to represent food safety laws and regulations, as well as analyzed the impacts of food safety policies on food trade ${ }^{[28-29]}$. Quantifying food safety policies instead of utilizing dummy variables may improve the accuracy of measurement. Besides, evaluating food safety policies based on empirical estimation of elasticity of substitution and preference parameters may avoid overestimating or underestimating the impacts of food safety polices. This study is performed to calculate the tariff equivalents of food safety policies on the basis of estimating the elasticity of substitution and preference parameters. The results from this study may provide some useful insights for foreign SBS rice producers and traders.

\section{Analytical framework}

Japan is supposed to be a rice importing country whereas foreign countries are supposed to be rice exporting countries. It is assumed that Japan is faced with changing imported rice prices that fluctuate with global grain prices. Besides, Japan's domestic rice prices depend on its market supply and demand. According to a study ${ }^{[30]}$, Japanese consumption of the composite of rice can be differentiated by their origins; for instance, rice from Japan and other countries are treated differently by Japanese consumers. More precisely, Dixit and Stiglitz's ${ }^{[31]}$ type of utility function ${ }^{[32]}$ had been adopted in this study. The Japanese consumption of japonica rice from Japan, China, U.S.A., and other countries is formulated. Maximizing consumers' utility function $U_{t}\left(D_{t}, I_{i t}\right)$ at the time $\mathrm{t}$ with an expenditure constraint and a quota limit for imported rice is expressed below:

$$
U_{t}=\left[a D_{t}^{\frac{\theta-1}{\theta}}+b I_{1 t}^{\frac{\theta-1}{\theta}}+c I_{2 t}^{\frac{\theta-1}{\theta}}+(1-a-b-c) I_{3 t}^{\frac{\theta-1}{\theta}}\right]^{\frac{\theta-1}{\theta}}
$$


Where $P_{d t} \cdot D_{t}+P_{1 t} \cdot I_{1 t}+P_{2 t} \cdot I_{2 t}+P_{3 t} \cdot I_{3 t}=E_{t}, \quad I_{1 t}+I_{2 t}+I_{3 t} \leq \bar{I}_{t}$

Where, $D_{\mathrm{t}}$ is the quantity of Japanese domestically produced rice; $I_{1 t}, I_{2 t}$, and $I_{3 t}$, each stands for the volume of imported SBS general rice from China, U.S.A., and other countries, respectively; $\bar{I}_{t}$ is the SBS rice quota; $P_{d t}$ is the prices of Japanese domestic rice; $P_{1 t}, P_{2 t}, P_{3 t}$ are the consumer prices of imported SBS general rice from China, the U.S.A., and other countries, respectively; $E_{t}$ signifies the limited expenditure on consuming japonica rice; $\theta$ is the elasticity of substitution that was introduced by Hicks ${ }^{[33]}$ and Robinson ${ }^{[34]}$, which is used to measure the degree of substitutability of one good for the other; $a, b, c$, and $(1-a-b-c)$ are Japanese consumers' preference parameters for domestic and imported SBS general rice, respectively. Japanese consumers' utility will be maximized and subjected to the budget constraint and import quota (1). The following is the constructed Lagrange function that yields the first order conditions $(i=1,2,3)$ :

$$
L=U_{t}+\lambda_{1}\left(E_{t}-P_{d t} \cdot D_{t}-P_{i t} \cdot I_{i t}\right)+\lambda_{2}\left(\bar{I}_{t}-I_{i t}\right)
$$

The Kuhn-Tucker conditions are as follows:

$$
\begin{gathered}
L_{I_{i t}}=U_{I t}^{\prime}-P_{i t} \lambda-\lambda_{2}=0 \quad I_{i t} \geq 0 \\
L_{D t}=U_{D t}^{\prime}-P_{d t} \lambda_{1}=0 \quad D_{t} \geq 0 \\
L_{\lambda_{1}}=E_{t}-P_{d t} \cdot D_{t}-P_{i t} \cdot I_{i t} \geq 0 \quad \lambda_{1} \geq 0 \\
L_{\lambda_{2}}=\bar{I}_{t}-I_{i t} \geq 0 \quad \lambda_{2} \geq 0
\end{gathered}
$$

In order to assess the values of the parameters, assuming that $\lambda_{2}=0$ and $\lambda_{1}>0$ from the equation (3) to (6), the next function (7), (8), and (9) can be obtained.

$$
\begin{gathered}
\frac{P_{1 t}}{P_{d t}}=\frac{b}{a}\left(\frac{D_{t}}{I_{1 t}}\right)^{\frac{1}{\theta}} \\
\frac{P_{2 t}}{P_{d t}}=\frac{c}{a}\left(\frac{D_{t}}{I_{2 t}}\right)^{\frac{1}{\theta}} \\
\frac{P_{3 t}}{P_{d t}}=\frac{1-a-b-c}{a}\left(\frac{D_{t}}{I_{3 t}}\right)^{\frac{1}{\theta}}
\end{gathered}
$$

$\frac{P_{i t}}{P_{d t}} \quad(i=1,2,3)$ represents the price ratio of the imported SBS general rice to Japan's domestic rice, and $\frac{D_{t}}{I_{i t}} \quad(i=1,2,3)$ represents the quantity ratio in a similar manner. The following estimated model (10) can be obtained.

$$
\ln \frac{P_{i t}}{P_{d t}}=\beta_{0}+\beta_{1} \cdot d_{2 i t}+\beta_{2} \cdot d_{3 i t}+\beta_{3} \cdot \ln \frac{D_{t}}{I_{i t}}
$$

Where $i=1,2,3$, and $d_{2 i t}\left(d_{3 i t}\right)$ is a dummy variable, which is equal to one if $i=2(i=3)$, otherwise it is equal to zero. Equation (10) will be estimated by the pooled OLS (ordinary least squares) method. Estimated coefficients are utilized to calculate the parameters in the utility function. 
Accordingly, the tariff equivalents of food safety policies can be evaluated. Consumer prices of imported SBS general rice in Japan, $P_{i t}$, consist of the following parts ( $i=1$, rice from China; $i=2$, rice from U.S.A.): $P_{o i t}$ indicates the prices of same-quality rice in the origin market; $F S_{i t}$ signifies the tariff equivalents of food safety policies (including the positive list system, traceability system, etc.); $C_{1 i t}$ means the transportation and insurance fees from origin market to Japan; $M P_{i t}$ is the markup imposed on imported SBS general rice by MAFF; $E C_{i t}$ is the extra cost for the import quota induced by MAFF's intervention (includes market investigation, tender costs, and so on), which is a type of specific tariff; $C_{2 t}$ represents the transportation fees charged from Japan's port to the supermarket.

$$
P_{i t}=P_{o i t}\left(1+F S_{\mathrm{it}}\right)+C_{1 i t}+M P_{i t}+E C_{i t}+C_{2 t}
$$

To maximize Japanese consumers' utility, the following relationship fulfills:

$$
M R S_{D_{t}, I_{i t}}=\frac{M U_{D_{i t}}}{M U_{l_{i t}}}=\frac{P_{d t}}{P_{i t}}=\frac{P_{d t}}{P_{o i t}\left(1+F S_{i t}\right)+C_{1 i t}+M P_{i t}+E C_{i t}+C_{2 t}}
$$

Where MRS represents the marginal rate of substitution between Japan's domestic rice and imported SBS rice while $M U$ signifies marginal utility. Combining equation (7), (8), (9), and (12), the tariff equivalents of food safety policies, $F S_{\text {it, }}$ can be calculated as specified in equation (13) where $x$ is equal to $b$ if $i=1, x$ is equal to $c$ if $i=2$, otherwise $x$ is equal to $(1-a-b-c)$ if $i=3$.

$$
F S_{i t}=\frac{1}{P_{o i t}} \cdot\left[P_{d t} \cdot \frac{x}{a} \cdot\left(\frac{D_{t}}{I_{i t}}\right)^{\frac{1}{\theta}}-C_{2 t}-C_{1 i t}-M P_{i t}-E C_{i t}\right]-1
$$

\section{Data processing and application}

The estimated sample period is chosen from 2000 to 2015 based on every fiscal year. All of the prices have been adjusted to real prices. $P_{i t}$ stands for the consumer prices of imported SBS general rice in Japan, which were initially substituted by MAFF's selling prices of SBS general rice chosen from the MAFF's website for estimating the parameters in equation (10). $P_{\text {oit }}$ signifies the prices of same-quality rice in origin market. As for SBS general rice from foreign countries, the prices of high-quality polished short-grain rice were obtained from the information website of Development Research Center of the State Council (DRCnet) of China. As for SBS general rice from U.S.A., the prices of California short-grain rice were obtained from the World Food Statistics and Graphics. $P_{d t}$ represents the prices of Japanese domestically produced rice, in which the wholesale prices of four types of Japan's domestic rice (Koshihikari, Akitakomachi, Hitomebore, and Kirara) were obtained from the World Food Statistics and Graphics. $I_{i t}$ indicates the imported quantity of SBS general rice from the MAFF's website. $D_{t}$ corresponds to the domestically produced quantity of rice in Japan according to the statistics by MAFF. $E_{t}$ is the Japanese family expenditure on rice quoted from the Statistics Bureau of Japan. $M P_{i t}$ is abbreviated for the markup imposed by Japan from the MAFF's website. $E C_{i t}$ is the extra cost induced by MAFF's intervention in the quota system, and the calculated results of $E C_{i t}$ can be referred to an article by Gao and other researchers ${ }^{[11]}$. $C_{1 i t}$ is calculated by CIF (Cost, Insurance, and Freight) prices minus FOB (Free on Board) prices. CIF prices can be found on the Japan Customs website, and FOB prices were obtained from the China Economic Information Network and the USA Customs website. $C_{2} t$ is shortened for the cost of transportation from Japanese seaport to the supermarket. The geographical distance is designated from Tokyo seaport to the center of the city in which the geographical distance is multiplied by railway fares, which can be found in the form (freight railway transport) offered by Japan's Policy Bureau and Railway Bureau, as well as the Ministry of Land, 
Infrastructure, Transport and Tourism. Besides, the Federal Reserve Bank of St. Louis supplied the data of the exchange rates of these currencies.

For the sake of examining the general rice consumption of Japanese consumers, 'integrated rice' has been constructed based on the average of Japan's four types of domestic rice (Koshihikari, Akitakomachi, Hitomebore, and Kirara). Accordingly, the prices of 'integrated rice' are defined as the volume-weighted average prices of Japan's four kinds of rice while the quantities of 'integrated rice' are the total Japanese consumption of domestic rice.

Before carrying out the pooled OLS regression of equation (10), it is necessary to check whether these variables are stationary or not using the unit root test. The results that are displayed in Table $\mathbf{1}$ implies that all the data are stationary at the original levels at $1 \%$ significance level.

Table 1. Results of the unit root test

\begin{tabular}{ccc}
\hline Series: $\ln \frac{\mathrm{P}_{\mathrm{it}}}{\mathrm{P}_{\mathrm{dt}}}, \ln \frac{\mathrm{D}_{\mathrm{t}}}{\mathrm{I}_{\mathrm{it}}}(i=1,2,3)$ & Sample period: 2000-2015 \\
\hline Method & Statistic & Probability \\
Levin, Lin, and Chu t & -5.226 & 0.000 \\
Im, Pesaran, and Shin W-stat & -2.876 & 0.002 \\
ADF-Fisher Chi-square & 36.384 & 0.000 \\
PP-Fisher Chi-square & 28.117 & 0.005 \\
\hline
\end{tabular}

Note: Null hypothesis is the unit root process. Results were calculated by using the statistical software EViews 8 .

\section{Results and discussion}

In view that these variables are stable at the original level, pooled OLS regression can be applied to estimate equation (10) to calculate the elasticity of substitution and preference parameters. Table 2 shows the estimated results of regression.

Firstly, by comparing the preference parameters in the whole sample period, the results in Table 2 suggested that Japanese consumers' preference parameter, which is based on the concept of ordinal rather than cardinal ${ }^{[35]}$, for Chinese SBS general rice, (b), was larger than that of SBS general rice from U.S.A., (c), or other main exporting countries, $(1-a-b-c),(b>c$ and $b>1-a-b-c)$ from 2000 to 2015. Due to its similar taste to Japanese japonica and having lower prices, Chinese SBS general rice was more popular in Japan's importing market of short-grain rice. In fact, most shares of Japan's imported SBS rice had been occupied by China for many years. Generally speaking, results have revealed that in Japanese SBS rice market, China had a stronger competitiveness compared with other main exporting countries like U.S.A. Besides, the elasticity of substitution $(\theta)$, that was bigger than one, indicated that the relationship between Japanese japonica and imported SBS general rice could be described as competitive instead of complementary. 
Table 2. Results of regression

\begin{tabular}{cccccc}
\hline Parameters & \multicolumn{5}{c}{ Period of food safety policies } \\
\hline Dependent & Food safety policies & \multicolumn{2}{c}{ Positive list system (PLS) } & \multicolumn{2}{c}{ Rice traceability (RT) } \\
variable: $\ln \frac{\mathrm{P}_{\mathrm{it}}}{\mathrm{P}_{\mathrm{dt}}}$ & (FSP) & & & Before RT & After RT \\
\cline { 2 - 6 } Independent & FSP $(2000-2015)$ & Before PLS & After PLS & $(2000-2009)$ & $(2010-2015)$ \\
variable: $\ln \frac{\mathrm{D}_{\mathrm{t}}}{\mathrm{I}_{\mathrm{it}}}$ & & $(2000-2005)$ & $(2006-2015)$ & $-0.431^{* *}$ & $-1.979^{* * *}$ \\
\hline$\beta_{0}$ & $-0.988^{* * *}(0.073)$ & $-0.273^{* *}$ & $-0.691^{* * *}$ & $(0.219)$ & $(0.364)$ \\
& & $(0.123)$ & $(0.083)$ & $-0.424^{* *}$ & $-1.573^{* * *}$ \\
$\beta_{0}+\beta_{1}$ & $-1.066^{* * *}$ & $-0.371^{* *}$ & $-0.595^{* * *}$ & $(0.205)$ & $(0.229)$ \\
& $(0.072)$ & $(0.175)$ & $(0.076)$ & $-0.516^{* *}$ & $-1.683^{* * *}$ \\
$\beta_{0}+\beta_{2}$ & $-1.101^{* * *}$ & $-0.547^{* *}$ & $-0.816^{* * *}$ & $(0.243)$ & $(0.231)$ \\
& $(0.081)$ & $(0.257)$ & $(0.083)$ & $0.410^{* *}$ & $0.745^{* * *}$ \\
$\beta_{3}$ & $0.443^{* * *}$ & $0.420^{* *}$ & $0.563^{* * *}$ & $(0.186)$ & $(0.117)$ \\
R-squared & $(0.106)$ & $(0.174)$ & $(0.117)$ & 0.23 & 0.62 \\
Durbin-Watson & 0.44 & 0.25 & 0.59 & 2.10 & 2.31 \\
$\mathrm{a}$ & 2.21 & 2.24 & 2.13 & $0.345^{* *}$ & $0.653^{* * *}$ \\
$\mathrm{~b}$ & $0.488^{* * *}$ & $0.330^{* *}$ & $0.401^{* * *}$ & $0.224^{* *}$ & $0.091^{* * *}$ \\
$\mathrm{c}$ & $0.182^{* * *}$ & $0.251^{* *}$ & $0.201^{* * *}$ & $0.225^{* *}$ & $0.135^{* * *}$ \\
$1-\mathrm{a}-\mathrm{b}-\mathrm{c}$ & $0.168^{* * *}$ & $0.228^{* *}$ & $0.221^{* * *}$ & $0.1206^{* *}$ & $0.121^{* * *}$ \\
$\theta$ & $0.162^{* * *}$ & $0.191^{* *}$ & $0.177^{* * *}$ & $2.439^{* *}$ & $1.342^{* * *}$ \\
\hline
\end{tabular}

Note: $* * * * *, *$ indicate $1 \%, 5 \%$, and $10 \%$ significance level, respectively. Numbers in parentheses are standard errors.

Secondly, comparing the results in periods before and after the implementation of the positive list system in Table 2, it can be observed that after the enforcement of the positive list system, Japanese consumers strengthened their preference for domestically produced rice while their preference for foreign rice became lower. Especially, the preference for SBS general rice from U.S.A. increased since 2006. Moreover, as the elasticity of substitution was used to evaluate how easy it is to substitute one good for the other, the decreasing elasticity of substitution revealed that it was much more difficult to substitute foreign SBS general rice for Japanese japonica perhaps because Japanese had a stronger will to consume domestic food. Technical barriers caused by the positive list system established a higher threshold for imported SBS rice so it was harder to substitute.

Thirdly, the results in periods before and after the enforcement of rice traceability in Table 2 implied that Japanese consumers' preference for imported SBS general rice decreased after the introduction of traceability while the preference for Japan's domestic rice increased. According to the regulation, information about product origin and delivery should be recorded on the labels of imported SBS rice required by the traceability. Therefore, the preference for foreign SBS rice and the substitution elasticity diminished.

Fourthly, compared with the positive list system, the rice traceability regulation had more significant influence on Japan's SBS rice imports because the reduction of preference for foreign rice and the elasticity of substitution were more drastic in the results from the traceability.

On the basis of elasticity of substitution and preference parameters, applying the empirical data into equation (13), the tariff equivalents of food safety policies, $F S_{i t}$, can be obtained. Figure 3 was drawn according to the calculated results of the tariff equivalents of food safety policies on SBS general rice from China and U.S.A., respectively. The tariff equivalents of food safety policies on the imported rice from 
China and U.S.A. were roughly similar to each other, fluctuating around $¥ 50$ yen/kg from 2000 to 2005 . A small peak occurred in 2002 because the MAFF of Japan carried out a designated markup criteria ${ }^{[36]}$. After the implementation of the positive list system, consumers' preference for foreign rice and the elasticity of substitution diminished as analyzed before. However, global grain prices have been rising since 2006 and the grain prices of U.S.A. have increased sharply. Meanwhile, the appreciation of Chinese currency resulted in higher prices of China's SBS rice valued in the Japanese currency. Besides, rice-exporting countries adopted more advanced and environment-friendly agricultural technology to comply with Japan's stringent quarantine. These above reasons narrowed the gap between consumer prices of SBS rice in Japan's market and the prices of SBS rice in the origin market, and therefore the tariff equivalents of the positive list system decreased after 2006.

A climax emerged in 2010 as shown in Figure 3 for the sake of Japan's rice traceability. As discussed before, consumers' preference for imported rice and elasticity of substitution decreased after the introduction of rice traceability, which made foreign rice less attractive.

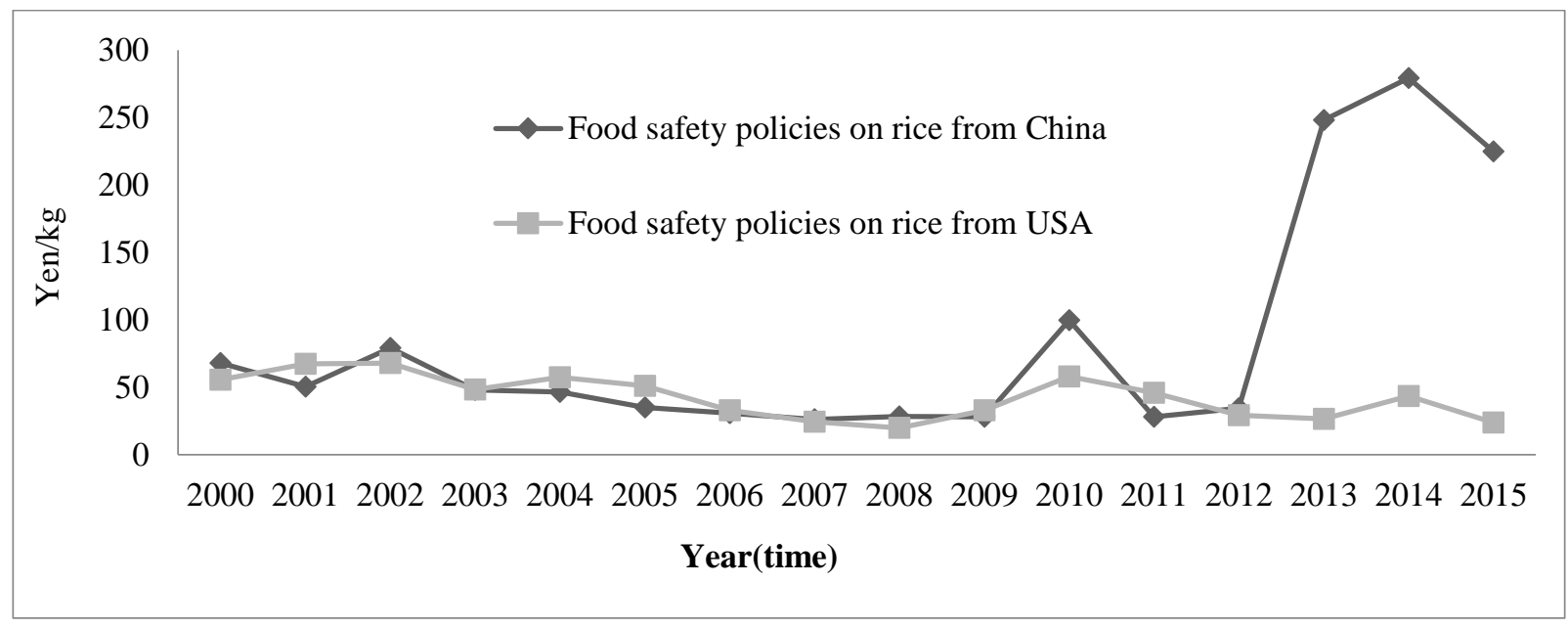

Figure 3. Tariff equivalents of food safety policies on SBS general rice

Note: The tariff equivalents of food safety policies were calculated by the author.

Therefore, the imported volume of SBS general rice slumped while the tariff equivalents reached the climax. Nevertheless, a catastrophic earthquake and tsunami attacked Japan in 2011, and the local rice production suffered a great strike. Soon afterwards, Japan's radioactive food from northeastern areas of the country scared the consumers. Consequently, Japan restarted to import large amounts of SBS general rice in 2011 and 2012, which offset the influence of the traceability. With the recovery from natural disasters, Japan cut down its SBS general rice imports again and the tariff equivalents of traceability on foreign rice soared higher after 2012. Figure 3 implies that the effects of rice traceability on Japan's SBS rice imports were much more significant than the impacts of the positive list system.

\section{Conclusion and policy implications}

This study empirically measured and evaluated the impacts of Japan's food safety policies on imported rice on the basis of estimated preference parameters and elasticity of substitution. The research found that Japanese consumers' favorite rice is domestically produced rice. As for the imported market, Japanese preferred China's SBS general rice compared to those from U.S.A. or other exporting countries on average during the sample period. Moreover, the estimated elasticity of substitution of imported rice and Japan's domestic rice was larger than one, which implied that SBS general rice could be regarded as competitive rather than complementary to Japan's japonica. Furthermore, after the enforcement of the positive lis $t$ 
system, consumers' preference for foreign rice and the elasticity of substitution decreased. These changes in the estimated parameters were quite similar to the results of rice traceability. Special attention should be paid to the period after the introduction of the positive list system or rice traceability because Japanese consumers' preference for foreign rice had changed. The calculated tariff equivalents of food safety policies fluctuated around $¥ 50$ yen/kg in regard to imported SBS general rice from 2000 to 2005 . Due to the global grain price hike and the development of environment-friendly agricultural technology since 2006, the tariff equivalents of food safety policies abated from 2006 to 2009. With the appearance of rice traceability, tariff equivalents of food safety policies increased in 2010, but natural disasters interrupted the increasing tendency. Subsequently, tariff equivalents experienced a soar again in 2014. In fact, the tariff equivalents of food safety policies on foreign SBS rice might be much higher as a result of traceability. Moreover, the stringent quarantine of Japan's food safety policies promulgation made the imported SBS rice less attractive and weakened the competitive power of foreign rice.

Therefore, first, the government and agricultural ministry of exporting countries should establish and promote a unified food certification system according to international food safety laws, covering the whole production process. On the basis of a comprehensive food safety system, local governments should supervise and inspect the entire chain of food industry, from the beginning of product farming to the end of food consumption. Second, the central agricultural ministry should make efforts to invest in agricultural research and technology to promote green agriculture and produce environmental-friendly food. Meanwhile, local agricultural departments should offer technical supports and subsidies to farmers to supply healthier rice. Besides that, the local government or trade association should also gather the overall rice business data and provide prompt warning as well as information to rice producers and processors. Third, as for main rice exporting countries, the government should actively take part in trade negotiations and procedures in constituting global food safety measures to struggle for equal rights.

\section{Funding}

This work was supported in part by the Fundamental Research Funds for the Central Universities, CUMT (Project No. 2017WA02).

\section{Disclosure statement}

The author declares that there is no conflict of interest.

\section{References}

[1] Takahashi D, 2009, Quantitative Evaluation of the Japanese Rice Policy Reforms under the WTO Agreement on Agriculture. Economics Bulletin, 29: 712-25.

[2] Bektasoglu B, Engelbert T, Brockmeier M, 2017, The Effect of Aggregation Bias: An NTB-modelling Analysis of Turkey's Agro-food Trade with the EU. The World Economy, 40(10): 2255-76.

[3] De Frahan BH, Vancauteren M, 2006, Harmonisation of Food Regulations and Trade in the Single Market: Evidence from Disaggregated Data. European Review of Agricultural Economics, 33(3): 337 60.

[4] Disdier AC, Marette S, 2010, The Combination of Gravity and Welfare Approaches for Evaluating Nontariff Measures. American Journal of Agricultural Economics, 3(92): 713-26.

[5] Fricke S, Chapman G, 2017, The Role of Standards in North-South Trade: The Case of Agricultural Exports from Sub-Saharan African Countries to the EU. Friedrich-Schiller-University Jena. 
[6] Genç M, Law D, 2014, A Gravity Model of Barriers to Trade in New Zealand. Treasury Working Paper Series, 14(05).

[7] Gu GD, Niu XJ, Zhang Q, 2007, Empirical Study on the Impacts of Technical Barrier to Trade on International Trade - Taking Tea Trade Between China and Japan as an Example. Journal of International Trade, 6: 015.

[8] Otsuki T, Wilson JS, Sewadeh M, 2001, What Price Precaution? European Harmonisation of Aflatoxin Regulations and African Groundnut Exports. European Review of Agricultural Economics, 28(3): 263 84.

[9] Wood J, Wu J, Li Y, et al., 2017, The Economic Impact of SPS Measures on Agricultural Exports to China: An Empirical Analysis using the PPML Method. Social Sciences, 6(2), 51. doi: $10.3390 /$ socsci6020051.

[10] Calvin L, Krissoff B, 1998, Technical Barriers to Trade: A Case Study of Phytosanitary Barriers and U.S.-Japanese Apple Trade. Journal of Agricultural and Resource Economics, 23(2): 351-66.

[11] Gao QH, Ito S, Ogundari K, et al., 2016, Evaluating Welfare Effects of Rice Import Quota in Japan: Based on Measuring Non-Tariff Barriers of SBS Rice Imports. Sustainability, 8(8): 817-29.

[12] Liu L, Yue CY, 2009, Non-Tariff Barriers to Trade Caused by SPS Measures and Customs Procedures with Product Quality Changes. Journal of Agricultural and Resource Economics, 34(1): 196-212.

[13] Nimenya N, Ndimira PF, de Frahan BH, 2012, Tariff Equivalents of Nontariff Measures: The Case of European Horticultural and Fish Imports from African Countries. Agricultural Economics, 6(43): 635 53.

[14] Beghin JC, Bureau JC, 2001, Quantitative Policy Analysis of Sanitary, Phytosanitary and Technical Barriers to Trade. Économie Internationale, 3: 107-30.

[15] Bao XH, 2005, Economic Assessment of SPS Measures Under the WTO Framework: An Analysis Based on Cost-Benefit. Finance and Trade Research, 5: 1-5.

[16] Jiang JY, Wang DW, 2009, Evaluation and Analysis of Non-Tariff Barrier that China is Faced with. Journal of Northeastern University (Natural Science), 30(6): 782-85.

[17] Bao XH, 2005, Economic Assessment of SPS Measures Under the WTO Framework: An Analysis Based on Cost-Benefit. Finance and Trade Research, 5: 1-5.

[18] Bigsby H, 2009, Measuring the Consistency of Phytosanitary Measures. Soil Science Society of America Journal, 69(4): 1066-8.

[19] Unnevehr LJ, Jensen HH, 1999, The Economic Implications of Using HACCP as a Food Safety Regulatory Standard. Food Policy, 24(6): 625-35.

[20] Chen YH, Nie PY, 2016, Duopoly Competition in Food Industry Considering Corporate Social Responsibility. Quality Assurance and Safety of Crops and Foods, 8(1): 33-40.

[21] Gawande K, 1997, A Test of a Theory of Strategically Retaliatory Trade Barriers. Southern Economic Journal, 64(2): 425

[22] Gawande K, 1999, Trade Barriers as Outcomes from Two-Stage Games: Evidence. Canadian Journal of Economics, 32(4): 1028-56.

[23] Yang B, 2007, The Cause of Technical Barriers to Trade: Game and Empirical Study. World Economy Study, 10: 41-7.

[24] Chang CC, Lee HL, Hsu SH, 2013, Food Security-Global Trends and Region Perspective with Reference to East Asia. The Pacific Review (East Asia and Food (in) Security), 26(5): 589-613. 
[25] Engelbert T, Bektasoglu B, Brockmeier M, 2014, Moving Toward the EU or the Middle East? An Assessment of Alternative Turkish Foreign Policies Utilizing the GTAP Framework. Food Policy, 47(47): 46-61.

[26] Fujiki H, 2000, Japanese Rice Market Liberalization: A Competitive Equilibrium Approach. Japanese Economic Review, 51(4): 492-518.

[27] Wu GS, 2012, A Quantification Research of Non-Tariff Barriers on China's Agricultural Product Import. Economic Survey, 1(5): 43-7.

[28] Chen LJ, 2011, The Effect of China's RMB Exchange Rate Movement on Its Agricultural Export: A Case Study of Export to Japan. China Agricultural Economic Review, 3(1): 26-41.

[29] Zhai YL, Pang H, 2011, Notice of Retraction Impact of Positive List System on Vegetable Trade between China and Japan. International Conference on E-Business and E-Government (ICEE), : 1-4.

[30] Dixit AK, Stiglitz JE, 1975, Monopolistic Competition and Optimum Product Diversity. American Economic Review, 67 (3): 297-308.

[31] Shan LJ, 2008, The Study of Vegetables Export of China Based on the System of Green Barrier to Trade. PhD dissertation, Jiangnan University, Wuxi City, China.

[32] Hicks J, 1932, The Theory of Wages, Macmillan London Press.

[33] Robinson J, 1933, The Economics of Imperfect Competition, Macmillan Press.

[34] Hayashi F, 2000, Econometrics, Princeton University Press.

[35] Fell J, MacLaren D, 2013, The Welfare Cost of Japanese Rice Policy with Home-Good Preference and an Endogenous Import Price. Australian Journal of Agricultural and Resource Economics, 57(4): 60119.

[36] Cai JS, 2004, Analyses on Structures of Minimum Access Rice Imports in Japan. PhD dissertation, Faculty of Agriculture in Tottori University, Japan. 